DOI:

Інна Агалець, кандидат педагогічних наук, доцент, старший науковий співробітник відділу наукової реферативної та аналітичної інформації у сфері освіти Державної науково-педагогічної бібліотеки України імені В.О. Сухомлинського НАПН України, м. Київ

\title{
ВПЛИВ СОЩАЛЬНО-ПЕДАГОГІЧНОГО СЕРЕДОВИЩА НА ПРОФЕСІЙНЕ САМОВИЗНАЧЕННЯ СТАРШОКЛАСНИКІВ
}

Висвітлено результати впливу низки умов соиіально-педагогічного середовища на вибір майбутньоі професії учнів стариих класів загальноосвітніх навчальних закладів (ЗН3) та акиентовано увагу на факторах, що впливають на розвиток соціального та особистісного самовизначення старшокласників. Наголошено, що навчально-виховний процес як система має забезпечувати поєднання психологічного, змістового, практичного та техніко-технологічного компонентів. Обтрунтовано доцільність запровадження в 3 З діагностування учнівської молоді з метою визначення рівня готовності до професійного самовизначення.

Ключові слова: сочіально-педагогічне середовище; професійне самовизначення; умови; мотиви; фактори; батьки; старшокласники.

Лim. 9.

Inna Ahalets, Ph.D.(Pedagogy), Associate Professor, Senior Researcher of the Department of Scientific Abstract and Analytical Information in the Field of Education of the State Scientific and Pedagogical Library of Ukraine named after Vasyl Sukhomlynskiy of the National Academy of Pedagogical Sciences of Ukraine, Kyiv

\section{INFLUENCE OF THE SOCIALAND PEDAGOGICAL ENVIRONMENT ONTHE PROFESSIONAL SELF-DETERMINATION OF STUDENTS OF HIGH SCHOOL}

The article highlights the results of the influence of a row of conditions of the socio-pedagogical environment on the choice of the future profession of the high school students of general educational institutions (GEIs). The scientific sources theme research is analyzed. It's marked that a primary purpose and source of efficiency of school education consists in all-round development of personality. The attention is focused on the vital issues of future GEIs graduates with regard to social and personal self-determination - the ability to develop their life plan, to determine their place in adult life. The essence of definitions "pedagogical environment", "professional self-determination" is considered. The main factors influencing the socio-pedagogical environment on the high school students' professional self-determination are traced. It was emphasized that the educational process as a system should ensure the fulfillment of important components: psychological, substantive, practical and techno-technological, which in turn ensure the functioning of the educational environment. The position is advocated on the necessity of conducting professional diagnostics of GEIs high school students in order to determine the level of formation of readiness for the professional self-determination. The position is advocated on the necessity of conducting professional diagnostics of high school students in the GEIs in order to determine the level of formation of readiness for the professional self-determination. The problem of the consequences of the negative influence of parents on the professional determination of their child has been violated. The expediency of cooperation of subjects of social and pedagogical environment is substantiated. The following conclusions are formulated: the implementation of successful and effective professional self-determination in the choice of a profession requires the creation of optimal social and psychological and pedagogical conditions for activating the processes of professional selfdetermination of the high school students. The most effective approach to choosing the ways of helping the high school students during the professional self-determination are the social and pedagogical environment.

Keywords: socially-pedagogical environment; professional self-determination; conditions; motives; the factors; the parents; the high school students.

П остановка проблеми. Специфічні соціально-економічні умови XXI ст. висувають нові вимоги до особистості майбутнього випускника загальноосвітнього навчального закладу (ЗН3). Випускник такого закладу має володіти компетентностями, які в Законі України "Про освіту" [8] визначено як комплекс характеристик особистості, що надає можливість їй ефективно діяти у різних сферах життя і діяльності.

Потреба (як мотив) і вміння старшокласників майбутніх випускників 3НЗ, вибудовувати життєву стратегію є показником соціальної компетентності особистості.

Як наведено в праці Н. Калініної, шкільне життя молодої людини охоплює період від 


\section{ВПЛИВ СОЦІАЛЬНО-ПЕДАГОГІЧНОГО СЕРЕДОВИЩА}

НАПРОФЕСІЙНЕСАМОВИЗНАЧЕННЯСТАРШОКЛАСНИКІВ

дитинства до повноліття, тому навчальний заклад $\epsilon$ тим соціальним інститутом, який сприяє цілеспрямованому формуванню стратегії іiі життєвого шляху. Учні в школі проходять кілька періодів входження у нове структуроване середовище, навчаються адаптуватися в ньому, набувати певних знань, умінь, життєвого досвіду [5].

Саме замолоду починається процес “створення" особистості, яка в подальшому стає суб'єктом праці та пізнання. Адже, чим більше культурно-історичного досвіду придбала людина і використовує в своїй діяльності, тим більш значуща вона як особистість для оточення $\mathrm{i}$ передусім для себе самої.

Тому професійний вибір старшокласників постійно є актуальним і значимим, оскільки стосується вирішального моменту в життєвому розвитку й становленні особистості.

Розв'язання зазначеної проблеми, пов'язаною 3 підтримкою учнівської молоді та створенням середовища для їх майбутньої самореалізації в соціумі, можливе за умови приділення цим питанням особливої уваги.

Метою статті $€$ висвітлення результатів вивчення низки умов, що впливають на свідомий вибір майбутньої професії учнями старших класів ЗНЗ.

Аналіз останніх досліджень і публікацій. Проведений аналіз наукових джерел засвідчує, що проблему професійного самовизначення та аспектів первинної професіоналізації особистості висвітлено в працях багатьох вітчизняних ученихдослідників: Е. Климова, І. Кона, Г. Костюка, В. Мадзігона, В. Моляко,Д. Ніколенка, С. Павлютенкова, К. Платонова, М. Пряжникова, С. Рубінштейна, М. Тименка, Б. Федоришина, М. Янцура та інших.

Виклад основного матеріалу. Зміна реалій суспільного життя зумовлює трансформацію поглядів на сучасну освіту, зокрема шкільну як базову ланку цієї системи, що має необхідні нормативно-правові можливості для розвитку потенціалу підростаючого покоління. “Основною метою і джерелом ефективності шкільної освіти $\epsilon$ всебічний розвиток особистості- творця нового людського життя. Шляхами реалізації цього складного завдання є самовдосконалення та подальша самореалізація учнів в обраних ними сферах майбутньої діяльності. 3 огляду на це важливу роль у цій справі має відігравати формування професійного самовизначення юнацтва, що розглядається як динамічний багатоплановий процес, який передбачає різноманітність підходів його забезпечення" $[1,72]$.

Важливими питаннями, над якими замислюються старшокласники, є осмислення себе й свого місця в житті в цілому, вибір майбутньої професійної діяльності, взаємини зі значимими для них людьми. Сформоване бачення життєво-важливих питань утворює психологічну платформу для соціального та особистісного самовизначення старшокласників і претендує на внутрішню позицію дорослої людини - вміння розробити свій життєвий план, визначення свого місця в дорослому житті.

Одне 3 головних місць у розв'язанні цієї проблеми посідає організація навчально-виховного процесу в навчальному закладі під керівництвом педагогів й у колі родини або близьких людей, тобто соціально-педагогічному середовищі. У "Педагогічному словнику" Г. Коджаспірової та А. Коджаспірова, визначено, що “середа педагогічна - спеціально, згідно з педагогічними цілями, створювана система умов організації життєдіяльності дітей, спрямована на формування їхнього ставлення до світу, людей і один до одного" $[6,142]$.

Як особисте життя, так і професія висуває перед будь-якою людиною певні вимоги, зокрема перед молодою особистістю, оскільки професійне самовизначення - це “< $<>$ ступінь самооцінки себе як фахівця певної професії; змістовний бік спрямованості особистості, що взаємодіє 3 визнанням; найважливіший об'єкт формування особистості в процесі професійної орієнтації' $[9,682]$.

У межах статті питання професійного самовизначення старшокласників пропонуємо розглядати 3 моменту вибору професії, який $є$ важливим етапом життєвого шляху будь-якої людини, їі розвитку і самореалізації, а первинну професіоналізацію - як процес, у результаті якого у молодої людини формується готовність до професійної діяльності, а це мотивація, наявність знань, умінь та професійно важливих якостей.

У психолого-педагогічних джерелах зазначається, що на розв'язання вищезазначених питань впливає багато факторів, під якими розуміємо умову, рушійну силу якогось процесу, явища; чинник, що впливає на результат [3, 1526].

Науковці виокремлюють фактори, що впливають на вибір професії, серед яких: обізнаність про світ професій і вимоги кожної 3 них, пізнавальні інтереси і особистісні якості співвідносити з професійним наміром, наявність спеціальних здібностей до певного виду професійної діяльності, стан здоров'я, а головне це соціально-психологічна атмосфера, яка сприяє або перешкоджає навчально-виховному процесу й всебічному розвитку особистості.

Значну роль у створенні сприятливих умов соціально-педагогічного середовища відіграють 
педагоги, їх психолого-педагогічна компетентність, стиль спілкування з учнівським колективом, надання учнівству кваліфікованої допомоги у виборі професії на основі вивчення та врахування їхніх інтересів і прагнень, індивідуальнопсихологічних особливостей, а також потреб ринку праці в кадровому поповненні.

Наголошуємо, що навчально-виховний процес як система має забезпечувати поєднання важливих компонентів психологічного, змістового, практичного та техніко-технологічного, які в свою чергу забезпечують функціонування навчальновиховного середовища. Зокрема, таке середовище покликано формувати атмосферу значимості, затребуваності, престижності знань, створювати мотивацію до навчання, бути спрямованим на формування пізнавальних інтересів (психологічний аспект); надавати можливість здобувати знання відповідно до пізнавальних потреб учнівської молоді (змістовий аспект); забезпечувати можливість подальшої самореалізації, тобто застосовування на практиці набутих знань та вмінь (практичний аспект); створювати сучасні умови навчання, до яких належать підручники, методичні посібники, роздатковий дидактичний матеріал, лабораторне устаткування та інструменти, використання сучасної техніки та інше [7].

Нами обстоюється позиція про необхідність проведення в ЗНЗ професійного діагностування підлітків старших класів (проведення бесіди й тестування), за допомогою якого педагогічні працівники отримують цілісне уявлення про сутнісні позиції у цьому напрямку щодо кожного учня. За наслідками проведеної роботи 3'ясовуються слабкі й сильні сторони підлітка, тобто яким питанням потрібно приділити більше уваги. Також мають значення психологопедагогічні тренінги зі світу професій, які нададугь старшокласникам можливість усвідомити свої здібності й потреби, зрозуміти наскільки ці професії підходять або не підходять та над чим варто ще працювати $[2 ; 4]$.

Умовою ж професійного i життєвого самовизначення учнів $\epsilon$ наявність у них професійно важливих особистісних якостей та здібностей, під якими слід розуміти окремі динамічні риси особистості, окремі психофізіологічні властивості, які відповідають вимогам сьогодення в багатьох професіях i сприяють успішному оволодінню ними.

Беззаперечним $є$ той факт, що на вибір майбутньої професії старшокласників впливає їхнє близьке оточення - родина та друзі, які належать до певного соціально-професійного прошарку й освітнього рівня. У колі родини відбувається взаємодія дітей і батьків, саме сім'я формує перші професійні орієнтири про світ професій батьків. Звичайно, що ще від народження й в процесі розвитку дитини батьки впливають на ії духовний світ. Це проявляється через механізм формування інтересів, розвиток здібностей та якостей, культивування ставлення до майбутньої професії, яке у старшій школі безпосередньо впливає на майбутній професійний вибір старшокласника.

Варто звернути увагу на можливі проблеми, що виникають внаслідок негативного впливу, оскільки існує вірогідність пригнічення авторитетом батьків бажання дитини в професійному визначенні. До таких проблем належать: низький рівень самоповаги старшокласника, несприйняття самого себе; відчуття непотрібності або навпаки - гіперопіки; спроби батьків прискорити процес вибору професії за допомогою власного авторитету, що можуть викликати у старшокласників небажання взагалі налаштовуватись на якийсь вибір.

Аналіз психолого-педагогічних джерел, спостереження й власний досвід свідчать про те, що, по-перше, з боку батьків необхідні дружня порада та консультування щодо професій, які зацікавили дитину, що відбувається в умовах атмосфери довіри та конструктивності; по-друге, постійна співпраця 3 педагогічним складом навчального закладу 3 метою отримання кваліфікованої допомоги в питаннях виховання, яких батьки повинні дотримуватись й профорієнтації, оскільки цей процес повинен буги цілеспрямованим і керованим, щоб майбутній випускник був здатний виважено підходити до планування і здійснення власної життєдіяльності.

Таким чином, зі створенням сприятливих умов навчально-виховного процесу, різноманітних за змістом та формою, кожний учень має можливість для реалізації активності, самостійності та самореалізації у навчальнопрофесійній діяльності. Провідним на цьому етапі $\epsilon$ соціально-педагогічне середовище, тобто підтримка найближчого оточення - педагогів, батьків, близьких людей старшокласника в усвідомленому виборі професії, сфери навчання, яка, зокрема, передбачає консультування 3 професійними психологами, педагогамипрактиками й батьками [1].

Доцільність співпраці суб'єктів соціальнопедагогічного середовища полягає в успішному розвиткуі подальшій соціалізації старшокласників у суспільстві. Такий підхід спроможний забезпечити розвиток кожного учня, створюючи 


\section{ВПЛИВ СОЦІАЛЬНО-ПЕДАГОГІЧНОГО СЕРЕДОВИЩА НАПРОФЕСІЙНЕСАМОВИЗНАЧЕННЯСТАРШОКЛАСНИКІВ}

умови, завдяки яким випускники старших класів зможуть швидко знайти гідне місце в соціумі, самореалізуватися як особистість.

Висновки 3 дослідження. Отже, реалізація успішного та ефективного професійного самовизначення у виборі професії потребує створення оптимальних соціальних і психологопедагогічних умов для активізації процесів професійного самовизначення старшокласників. Найбільш результативним підходом до вибору способу надання допомоги старшокласникам у період професійно-особистісного самовизначення $\epsilon$ соціально-педагогічне середовище.

Перспективи подальшого дослідження вбачаємо у вивченні шляхів співпраці навчальних закладів з батьками, тобто форми, прийоми та способи спільної діяльності для продуктивного результату професійного самовизначення старшокласників.

\section{ЛIТЕРАТУРА}

1. Агалець І. О. Психолого-педагогічна підтримка старшокласників у професійному самовизначенні [Електронний ресурс]: реф. огляд / уклад. Агалець I. О. // Аналітичний вісник у сфері освіти і науки / НАПН України, ДНПБ України ім. В. О. Сухомлинського. Текст. дані. - Київ, 2017. - Вип. 5. - С. 72-84. - Режим доступу: http://dnpb.gov.ua/wp-content/uploads/2017/ 05/Analituchnuy visnuk 2017-5.pdf (дата звернення: 10.10.2018).

2. Бочелюк В. Й. Педагогічна психологія: навч. посіб. / В. Й. Бочелюк, В. В. Зарицька. - Київ: Центр навч. літ., 2006. -248 с.

3. Великий тлумачний словник сучасної української мови (з доп., та CD) / [уклад. і голов. ред. В. Т. Бусел]. Київ; Ірпінь:Перун, 2007. - 1736 с.

4. Вікова та педагогічна психологія: навч. посіб. / О. В. Скрипченко, Л. В. Долинська, 3. В. Огороднійчук [та ін.]. - Київ: Просвіта, 2001. - 416 с.

5. Калинина Н. В. Формирование социальной компетентности как механизм укрепления психического здоровья подрастающего поколения / Н. В. Калинина // Психол. наука и образование. -2001. -№ 4. - С. 16-21.

6. Коджаспирова Г. М. Педагогический словарь: [для студентов высш. и сред. пед. учеб. заведений] / Г. М. Коджаспирова, А. Ю. Коджаспиров. - Москва: Академия, 2001. $-176 \mathrm{c}$.

7. Кремінський Б. Г. Функції освітнього середовища 3 точки зору створення умов для роботи з обдарованою молоддю / Б. Г. Кремінський // Наук. часопис Нац. пед. ун-ту ім. М. П. Драгоманова. Серія 5, Педагогічні науки: реалії та перспективи: зб. наук. пр. / НПУ ім. М. П. Драгоманова. - Київ, 2016. - Вип. 53. - С. 102108.

8. Про освіту: Закон України від 5 верес. 2017 р. № 2145-VIII // Відом. Верхов. Ради України. - 2017. № 38/39. - Ст. 380 .

9. Современный словарь по педагогике / [сост. Е. С. Рапацевич]. - Минск: Соврем. слово, 2001.-928 с.

\section{REFERENCES}

1. Ahalets, I. O. (2017). Psykholoho-pedahohichna pidtrymka starshoklasnykiv u profesiinomu samovyznachenni [The psychological and pedagogical support of senior pupils in the professional selfdetermination].[Electronnic resource]. An analytical newsletter in the field of education and science. Kyiv, vol. 5,pp. 72-84. Available at: http://dnpb.gov.ua/wp content/uploads/2017/05/Analituchnuy_visnuk_20175.pdf(accessed 10.10.2018). [in Ukrainian].

2. Bocheliuk, V. Y. \& Zarytska, V. V. (2006). Pedahohichna psykholohiia: navch. posib. [Pedagogical Psychology: Textbook]. Kyiv: Tsentr navch. lit., 248 p. [in Ukrainian].

3. Busel, V. T. (Ed.) (2007). Velykyi tlumachnyi slovnyk suchasnoi ukrainskoi movy [Great Explanatory Dictionary of Modern Ukrainian Language]. Kyiv; Irpin: Perun, 1736 p. [in Ukrainian].

4. Skrypchenko, O. V., Dolynska, L. V. \& Ohorodniichuk, Z. V. et al. (2001). Vikova ta pedahohichna psykholohiia: navch. posib. [The Age and Pedagogical Psychology: a manual]. Kyiv: Prosvita, 416 p. [in Ukrainian].

5. Kalynyna, N. V. (2001). Formyrovanye sotsyalnoi kompetentnosty kak mekhanyzm ukreplenyia psykhycheskoho zdorovia podrastaiushcheho pokolenyia [The formation of social competence as a mechanism of strengthening the mental health of the younger generation]. Psychology, Science and Education, no. 4, pp.16-21.[in Russian].

6. Kodjaspirova, G. M. \& Kodjaspirov, A. Yu. (2001). Pedagogicheskiy slovar [Pedagogical Dictionary]. Moskva: Akademiya, 176 p. [in Russian]

7. Kreminskyi, B. H. (2016). Funktsii osvitnoho seredovyshcha z tochky zoru stvorennia umov dlia roboty $\mathrm{z}$ obdarovanoiu moloddiu [The functions of the educational environment in terms of creating the conditions of working with gifted youth]. Scientific journal of the National Mykhaylo Drahomanov Pedagogical University. Series 5, Pedagogical Sciences: Realities and Prospects. Kyiv, vol. 53, pp.102-108. [in Ukrainian].

8. Pro osvitu: Zakon Ukrainy vid 5 veres. $2017 \mathrm{r}$. № 2145-VIII [On Education: The Law of Ukraine of 5 September. 2017 p. № 2145-VIII]. Vidom. Verkhov. Rady Ukrainy, No. 38/39, art.,380. [in Ukrainian].

9. Rapatsevich, E. S. (Ed.). (2001). Sovremennyiy slovar po pedagogike [Modern Dictionary on Pedagogy]. Minsk: Sovrem. slovo, $928 \mathrm{p}$.

Стаття надійшла до редакції 18.10.2018

\section{G58089

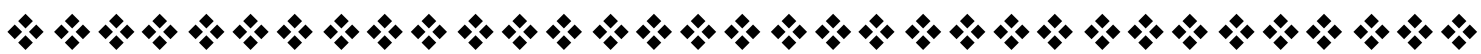

